\title{
The Development Strategy of the Private University in China
}

\author{
Liao Yu \\ Department of Business Management, City College of Wuhan University of Science and \\ Technology, East lake ecological scenic spot, Wuhan, China \\ tomliao-898@163.com
}

Keywords: Private University, Problem, Strategy

\begin{abstract}
With the rapid development of China's economic and social, the people's demand for higher education is higher and higher. In recent years, private colleges and universities have blossomed; it explores a new effective channel for the development of China's higher education. This article analysis the origin and role of private colleges and universities, discussed Problems existing in the development of private colleges and universities, and put forward the corresponding development strategy.
\end{abstract}

\section{Introduction}

Private University is the non-government college, which refers to the main stay by private capital in business; it relies on the student's tuition fees for university business. This kind of university is generally more expensive, but its environment and the education condition is better. Although the main funding source of the private colleges and universities rely on tuition fees, donations and fundraising, in order to maintain the characteristics of an independent non-profit organizations, but also some private universities still accept government funds, Such as Cornell university, its four colleges will rely on the federal government's subsidy[1].

\section{The origin of the private colleges and universities}

Private university led by the top institutions of higher education in the United States, because its money is convenient to use, its alumni and enterprise are willing to donate, and also enjoy government subsidies as public university. Under the scholarship funding, private universities tend to monopolize the most outstanding students. Almost all of the top 20 university is a private university in USA, its alumni and professors won the world's most Nobel Prize.

There are more than 4000 institutions of higher education in the United States, private university accounts for more than half. Also, the most top universities are private. According to the U.S. News \& World Report, the top 10 are all private universities in the University ranking in 2014, in the first 20 college, only University of California, Berkeley, is a public University. In fact, the history of the private colleges and universities more long more than public colleges and universities in the United States. The eastern traditional famous universities such as ivy league 8 colleges and universities are private universities. Before the 19th century, private colleges and universities had been dominated the lifeblood of higher education in the United States.

Before the independence, institutions of higher education are completely private, and were mainly controlled in the hands of the church. At this time these universities mainly imitate the 
Oxford, Cambridge University, UK. America's first university is the Harvard College, which is the predecessor of Harvard University today. Harvard college was founded in 1636 by the Massachusetts colony, in order to train pastor. To commemorate the Puritan minister John Harvard, his generosity for putting half of his savings 720 pounds and more than 400 books were donated to the school, the grand court of Massachusetts ordered named it as Harvard college on March 13 in 1639.

Yale university is the eponymous university with Harvard University, its predecessor was Yale College, which was founded in 1701. On October 9, 1701, Connecticut colony court passed legislation to establish University College. Shortly after, 10 Congregationalist Minister entrusted management of school established the first school library through providing the few books from their collection of books. These ten priests were all the graduates of Harvard College, now they were all considered the founder of Yale university. in 1718, a British businessman Elihu Yale who Was born in Boston, donated nine bundle of goods (for sale income of more than 560 pounds), and 417 books and a portrait of king George I to the school. In order to thank Mr. Yale's donation, officially changed its name to Yale College.

To 1776, before the United States independence from colonial rule, there were formed ten universities in the United States, were all private universities. They are: Harvard College, Yale College, William and Mary College, New Jersey College, King's College, Queen's College, Philadelphia College, Rhode Island College, Dartmouth College, Pennsylvania College. The main motivation founded the university is religious as the similar purpose of the Harvard college and the Yale college, its aim is to foster a profound knowledge of missionaries, church workers and government officials piety to religion. 10 universities were basic run by the church, the main courses are Latin, Greek, Hebrew, bible study, ethics, the neo-Confucianism, rhetoric, a preliminary mathematical knowledge and concise history and natural science knowledge.

After the federal government was founded, the new government realized deeply which education is related to the rise and fall of the country.befor 1800 , there were only 25 private universities in the United States, only a few students, higher education rely completely on private groups. Dartmouth college had been established by the priest named Eleazar Wheelock helping to raise funds in the UK, it was approved by King George III in December 13, 1769. the school was named the name of the William Legge, the Earl of Dartmouth. In order to promote the development of education and the need of social economy, the new government is determined to create more colleges and universities. In 1816, the government is trying to change Dartmouth college to state schools, aroused the strong opposition from the school. Dartmouth College's appeal to the federal Supreme Court, court ruling Dartmouth college victory to maintain independence in 1819. the decision further reiterated and confirmed private sector (especially the church) have permissions, and can not be accepted by the government under the condition of free development, thus stimulating the enthusiasm of the private groups in running schools, they established many private colleges and universities.

During this period, the new government argued that higher education should be presided over by the government, state governments' attempting by receiving private colleges and universities to change into the state universities doesn't work, so only to developed state colleges and universities by grant. However, the limited excellent students become racing resources, the advantages of state colleges and universities are low tuition fees, it become the ideal choice for many students. private colleges and universities have a sense of urgency and crisis from racing, they further improve the university teaching quality through a variety of measures for students.[1]

\section{The origin and role of China's private colleges and universities}

China's first private modern university, Dongwu university, it founded in Suzhou by Christian 
supervision in 1900, which awarded the first bachelor of arts degree in China. Before the May 4th movement, China's higher education has been in private universities as main body, and is not registered to the central government, the board has full autonomy. after 1949, Private university in mainland of China changed into public universities, for a long time, public universities keep monophony positions, Until the $1980 \mathrm{~s}$, the government began allowing the establishment of private colleges. YangEn university founded in 1987, it is the first China's private universities can award national bachelor degree certificate and award bachelor's degree qualification after 1949. As of May 2016, mainland China has 722 private universities (including independent college). Private higher education in our country is developed gradually since the reform and opening to the outside, after more than 20 years of exploration and development, its position and function is increasingly recognized by government and the society, and become the important component of the socialist cause of higher education. The role of private colleges and universities in our country is as follows:

\subsection{It is helpful to realize education fairness and equality}

With the enrollment expansion of the higher education year by year, the number of students going into the university then increased year by year. but even in the stage of popularization of higher education, there are still about half of people outside the university. And the emergence of private universities, no doubt, promoted the education fairness and equality. The existing public schools is difficult to meet the needs of the students and parents in terms of scale, quality, characteristics. In the conditions public schools are difficult to meet demand, there requires private schools to meet the desire of the people. Non-government college will not only satisfy the right of people to receive education, and satisfy the people to choose the right to education; they achieved the purpose of their own profit, private universities cultivated social needed talents, to achieve the "win-win" of itself and society. The biggest beneficiaries are country. Not only private schools compete with other private schools, and compete with public schools, prompting schools' change, they are advantageous to the consumer and promote the fair and equal of the education.

\subsection{It is advantageous to the national economic development and social stability}

In the first, the development of private colleges and universities can raise revenue. Private university located in a profit-making industry, it must pay taxes; to prevent profiteering, countries may adjust the control them by way of tax regulation, which obviously increase the national income. Second, it can alleviate employment pressure. Non-government college requires more teachers, they solved the employment problem of one part person in present; because it can set up professional social need, this is helpful to the employment of graduates. Again, it can pull the education consumption. At present, family and personal demand for the quality of education and education level stronger than any other time. From the point of the urban residents' consumption expenditure proportion, the average growth rate of education consumption education consumption achieved $20 \%$, it is the fastest growth projects, The emergence of private university meet the people's growing demand of education.

\subsection{It is helpful to resist foreign education institutions are in occupation of education market in China}

China's huge education market attracted many foreign educational institutions, Now there had more and more foreign education institutions entered China's education market, the war attract students intensified. But only the educational condition in the present, it is difficult to compete with foreign education institutions. And some foreign education institutions and group have occupied the Chinese part of the talent market in a variety of preferential conditions. Because many students study abroad through various means leading to a large number of funds going abroad. And through the development of private university, it not only retain talent, and saved money, at the same time 
can enhance the competitiveness of our universities in the education market.

\section{The development problems of private colleges and universities}

\subsection{Identity discrimination}

Today in China, the colleges and universities is divided into three classes by means of administration, the colleges and universities directly under the ministry of education are in the first class, there are the so-called "985 project", "211 project". Local public colleges and universities are in the second class, And private colleges, it is late. there is a big gap compared with private university and public universities, Many treatment of staff in private colleges is very low, such as wage subsidies, social security and retirement benefits, title evaluation, policy for children going to school, etc. teachers in private colleges has been in a state of instability. one of the most serious, private colleges not being treated fairly in graduates' employment. Some units, enterprises take discriminatory policies for private universities graduates in the recruitment; it has affected the development of private colleges.

\subsection{Recruitment problems}

Private colleges are facing increasingly serious crisis of students, as the change of population structure in our country, higher education school-age population is a trend of decrease year by year. Since 2008, higher education school-age population began to decline. Some public universities also compete with private colleges; some public universities also opened the network school to attract some of the students of lower test scores in addition to traditional specialized subject education in recent years, This threat to private colleges become more and more serious.

\subsection{Development funding problems}

The funding structure of private universities is quite single, mostly rely on tuition fees to maintain and develop. And private colleges only carry on the hardware construction under the condition of scale for the primitive accumulation of capital. But tuition as the mainstay of the funds, when students is bad, capital operation will be short, not to mention increasing investment. Moreover, from the perspective of the development of the future, the growth of the tuition of higher education in the mainland is limited, Because at present China mainland, annual tuition and fees charged by colleges and universities have been $80 \%$ of urban residents per capita annual income, $200 \%$ of rural residents' annual per capita income, was greatly out of the reach of the mainland residents' annual per capita income. Once again raise tuition and fees of higher education institutions is not appropriate.

With the improvement of government for private colleges education standards, the establishment of full-time teachers, increasing faculty salary, etc., the cost of education must be improved, to accumulate funds on tuition income will become more and more difficult, it is restricting the further development of private higher education career; At the same time China regional economic development is imbalance, regional difference is obvious. In the developed area, the folk has the resources in running school; ordinary people can afford to pay tuition fees, so that private education can develop. In less developed areas, just the opposite. In short, if the private colleges and universities rely only on tuition income, it is difficult to have a big development.

\subsection{Attracting talent problem}

Teachers in private colleges are unable to enjoy the same treatment as those teachers in public colleges and universities, this situation lead to the low teachers' professional identity. According to the survey shows that there are not less than $84 \%$ of the teachers to look themselves as employees in 
private schools, the lack of the sense of responsibility led to private college teachers turnover, team is unstable; Private colleges generally have more young teachers, retired teachers and part-time teachers, and there is a shortage of middle-aged teachers which owned teaching and management experience, especially the lack of first-class professors and academic leaders, team's fault, the title and degree structure is unreasonable, the lack of academic research atmosphere, is not conducive to the sustainable development of the school. To recruit or employ less than more high level teachers, to improve teaching quality, it prevent the further expansion of the private colleges, even threaten the survival of private colleges.

\section{The strategy of the development of private colleges and universities in our country}

Through the above analysis, for the development of private colleges and universities in China, I think have the following strategies:

\subsection{The funds in private colleges and universities can dlraw lessons from the American model}

Reviewing the development of private colleges and universities in the United States, its donation model is worth our using for reference. Before the end of the civil war in 1865, the church is the founder of colleges and universities, but because there is no direct income, they more rely on collection. After the war ended, American business and industry to accelerate the development of the concentration of capital and large enterprises were founded, many entrepreneurs donated funds and real estate, established a lot of university to promote the need of talent training, at the same time, you can pay less tax. The relations with Private colleges and universities and government are more alienated, donations from alumni, businesses, foundations, become one of the main sources of funding private colleges and universities. In addition, the main funding sources of private colleges and universities include: (1)its charging tuition fees are usually higher than public colleges and universities, the sources of funds the proportion is bigger also, some accounts for about $60 \%$ of the total revenue; (2)Local, state and federal purposes specified subsidies provided by the government; (3)the researching and service contracts from government agencies, foundations, enterprise, etc.

\subsection{The use of capital market on funding}

Higher education should make full use of capital market, issuing bonds and lottery tickets. First of all, the government can through the issuing of education bonds to complement the shortage of education funds; second, striving for the social donation. With the increasing of personal income, the continuous improvement of the social welfare and charity, social donations will be increased; Again, strive for international education funding. International education funding is provided by international agencies on education development in developing countries, to help the revitalization of the national economy, the development of education cause. From the perspective of the trend of development, the level of funding will have certain growth. Their main projects are the school construction, teaching equipment, library, etc.

\subsection{The government policy on the fostering of private colleges and universities}

"Private education promotion law" specific provision the private and public schools have the equal legal status in our country but there are some policy in our country has not been fully implemented, the obstacles is set in the execution, For example, some local tax department look private colleges as a private enterprise, to levy income tax for the distribution; Private colleges' heating fee standards are higher than public colleges and universities in the land, buildings, water, electricity, and according to the enterprise's standard rate, etc. 


\subsection{Accurate positioning and adjust measures to develop from local conditions}

As a private colleges they should be accurate positioning, private universities want to achieve sustainable development, its development planning must be fully reflect national, local and school's own interests and requirements, to be able to with the guiding ideology of the state and local education development, they should have innovative ideas and advanced consciousness When make the school development planning, they will make full use of local government policy for the development of private higher education, they should speed up the development, expand their own power from the background of regional development of higher education to look for the development space is suitable for their own .

\subsection{Building the sustainable development of the teachers}

Teacher is the essence of the private colleges and universities, there is no one teachers' team can be sustainable development, then it is impossible to realize the sustainable development of private colleges. First of all, to optimize the structure of teachers, promote the sustainable development of teachers. Private colleges in building their own teachers should have a sufficient number and relatively stable full-time teachers, full-time and part-time teachers and maintain reasonable proportion; secondly, improving the teacher training mechanism, strengthen the training of teachers, To actively trying to build a substantial "double type" teachers, to adapt to the private higher education to achieve the goals of sustainable development; Again, you must insist on humanistic management, respect and care teacher, stimulate the teachers' working passion and enthusiasm.

The general population base of China's higher education is big, its poor foundation, poor infrastructure, countries do not have more money into higher education. The private colleges as the supplement of state higher education since established in 1980, is developing rapidly and became an important part of higher education, and has played a positive role in promoting the process of popularization of higher education, we must not be lost this huge development potential education position.

\section{References}

[1] http://baike.so.com/doc/1151220-1217872.html.

[2] Dongshenzhu. the new expectation for private education[J]. Education development research. 2014(03).

[3] Panmaoyuan. the orientation and development of the transformation of the independent college [J]. Journal of southwest jiaotong university (social science edition). 2014(05).

[4] Wangyitao. the public welfare of private colleges in our country [J]. Education development research. 2010(18).

[5] Zhangyinqiu. how to achieve healthy and rapid development for private education[J]. Guangdong education (comprehensive). 2016(02). 